\title{
The Protagonist passion for power in Shobhaa De's Sethji
}

\author{
Dr. Jabeen Rafiuddin Siddiqui
}

\begin{abstract}
Shobhaa De a true artist, a fearless novelist and columnist who portrayed the life of urban elite people to bring in focus the dark view of their lives in front of the society. As a feminist she writes different than other female writers Anita Desai, Shashi Deshpande, Bharati Mukherjee, Jhumpa Lahiri, Manju Kapur and others. She provides complete freedom to her female characters to overcome their difficulties whether they had to sell their souls. The protagonist Amrita's life, her predicaments and the passion to achieve the power is been described in this article. The circumstances in her life were so adverse but she accepted the unalterable facts of life confidently. She strives against the ravenous male-dominated society. She was Sethji biggest asset used by him in politics. She was influenced by her mother and adopted her mother's belief and values and psychologically copies her mother how she had struggled and married twice for the sake of money and survival and regain power. She breaks down all restricted unlawful boundaries by compromising her virginity with the lustful manoeuvers to Sethji and assumes her goal to become a powerful woman.
\end{abstract}

Keywords: Ravenous, empowerment, opponent, accountable, incestuously, disenchanted,restlessness, manoeuvers, st ubbornness, exquisiteness, womanhood, epilepsy.

\section{Introduction}

The paper introduces the protagonist Amrita's passion of power in Shobhaa De's novel Sethji. Shobhaa De's fiction portrays the contemporary reality of the rich elite people whether they are rich businessman, politicians, Bollywood actors, producers, doctors and industrialists. She delves deep into the hearts of the people and exposes the reality to the world without aiming to harm anyone. She is straight forward and talks with guts and fearlessness focusing her work to rule out the dangers developing in the society and to bring the awareness in the society. Her work is unique, innovative and interesting. De is a true artist who judges the demand of her modern characters. She is the first among the feminists who lifted the condition of modern elite females of contemporary India. Her works differ from other female feminist writers like Anita Desai, Shashi Deshpande, Bharati Mukherjee, Jhumpa Lahiri, Manju Kapur and others. They painted the plight of grief and heartrending condition of Indian women in the male controlled society and made English novels exciting and rich. As a feminist De gives complete freedom to her female characters to expand their wings and to enjoy the life for their utmost betterment whether they may have to sell their souls. She is influenced with the feminist writers like Libba Bray, Maureen Johnson, Margaret Atwood, Tina Fey, Jessica Valenti and Jill Abramson who embrace womanhood and women's right for her empowerment. She is also a grandiloquent advocate of feminist thoughts and she knits her characters in such a way giving them a chance to overcome their absurd behaviours. She had also given the voice to the pain of her female characters, desires and justifications of women in a traditionally patriarchal world. Her characters they leave no stone behind to achieve the success. They are just worthy when measured against men. Negativity approaches them easily. The novel Sethji has been explored and interpretated to study the passion of power in Amrita. The novel was read thoroughly. Her best sold novels are Socialite Evenings(1989), Starry Nights(1992), Sisters(1992), Strange Obsession(1992), Sultry Days(1994), Snapshots(1995) and Second Thoughts(1996).

Shobhaa De's sizzling novel Sethji published in 2012 exposes the dark amoral heart of Indian politics. The De's novel is about ambition, greed and lust. In Sethji the power becomes erotic and the protagonist didn't want to lose the battle. In this novel De changes the script to bring the dark face of politics in front of society. The novelist is assured that like Sethji there are many politicians who are such sleaze and are disguising to hide themselves. She observes her characters from the society and paints them efficiently in her fiction. She uses the brilliant use of Hinglish language to understand the readers fully the image of the characters and adds humorous effect and charm to her novels. The paper defines the desire of Amrita to achieve the power to protect her from the unkind fate selling the soul.

\section{Discussion}

Power is frequently defined as the capability of producing an effect, whether physical or moral and also influencing the conducts of the individuals. It can be viewed as good and bad affecting the people as endemic. In contemporary society a change can easily be visualize to become a powerful person. Shobhaa De appropriately has brought economic facet of power struggle, she utters: 
"Eventually everything boils down to money-that great leveller. There can be no talk of independence for women, without economic self-sufficiency. An independent mind of free spirit is meaningless so long as the body and soul are being kept together by somebody else.,"

In Sethji Amrita's life is a perfect example of restlessness because she struggled from start to end for her survival. To settle with any relationship she has to boil herself and then to settle it and again adjust with the new one. She develops her subconscious mind to acknowledge in a positive and constructive way to every problem or difficulties coming in her life.

Sethji is the head of Azad Bharat Socialist Party, a crucial coalition partner in the government. He was by caste a nhaai and is shrewd, ruthless and an old spiteful fighter. He was the first man from their community to emerge as a national figure. He had begun his political career by taking a loan of five lakhs rupees from Amrita's father Seth Jamanlal and thought that adverse situation may also come. The dark secret about him was that there was a pinkish leucoderma stain on his groin. His daughter-in-law Amrita is beautiful, ferocious and imperious. She controlled every aspect of Sethji's life from food on his thali to the favours he doled out. She ruled over Shanti Kutir Sethji's sprawling colonial bungalow located in the heart of New Delhi. Her husband Srichand, Sethji's elder son, failed to fulfil his wife's sexual desires. Amrita suffered in her life at each level. In her parental home after her father's death, she had undergone a tragic change. She remembers:

"She'd watched her mother struggle in a way that had made her determined never to be in such a way that had made her determined never to be in such a pitiable position herself. Money became a sickness and an obsession. There was never enough of it. With Seth Jamanlal dead, large portions of his land had been grabbed by his cousins, leaving his helpless widow with only a few, comparatively less fertile, acres. "2

She had noted her mother struggling in her life to meet the ends meet and thought that she will not led herself in such a miserable situation. In her childhood money became an ailment and also a delusion for herself. Her mother somehow manages through the estate to pay Amrita's School fees and their insufficient daily needs. Amrita became the head of the family and dealt with many people demanding debt taken by her father late Seth Jamanlal. The land was sold portion by portion and there remained a small outhouse where the staff used to reside earlier. She started to give tuitions to girls in the neighbourhood. Her students used to come her home for tuitions. Her mother pronounces:

"Young girls are like delicate flowers. Their petals get crushed just once. After their fragrance is destroyed, what remains for anybody to enjoy? A crushed flower has zero value in a bouquet. No vendor will touch it."

After few years struggling to keep up appearances her mother remarried to a wealthy Delhi based businessmen, Raghubir Prasad who belonged to a neighbouring zamindar family. And the family moved to Delhi. Her step-father was a good man, good to her and to her mother. He suffered from epilepsy and felt guilty about having concealed this from Amrita's mother trusting before the marriage. After a decade had passed Raghubir Prasad has passed away and her mother was called as a husband killer. In the funeral of her step-father she saw her future husband Srichand accompanied by his father Sethji. Sethji promised to repay back the debts completely by proposing Amrita to his son Srichand. They had given money to her mother as a help. Her mother said:

"Your real father left us years ago, with absolutely nothing. It is our time to pay back Sethji for saving us. We owe it to him. You have seen how society has shunned us after Raghubirji's death. Who will marry a girl whose mother's reputation is so tainted?"

Her mother also wanted that she should win Sethji's heart. The circumstances in her life were so adverse but she accepted the unalterable facts of life confidently. Amrita possess dusky complexion, dark eyes that invited men to drown in them. She possessed absolute assurance and was ready to face each and every difficulty coming in her way of life. At each phase of her life she had to trigger greater challenges because she knew that success lies on the far side of failure.

She snorted and protested the proposal, cried, shut herself in her room, refused to eat and bathe .She didn't want to reject her love with MK which she dreamt of a good future .But her mother forced and compelled her telling that she will not get a better alliance of marriage than Sethji's son. Srichand promised her that he will give her a better future, a better life than MK. She listens carefully the words of Srichand and surrendered herself to him affirmatively.

"Marrry me! I will give you the best future. The best life. You will be treated like a queen in our home. And you will always be the empress of my heart, Amritaji. I love you!'It was a declaration she had no defence against" .

She also wanted her maid Phoolrani's life to change as irrevocably as that of her mistress. Her bedroom was full of fragrances, it was spacious and she felt irrationally calm. In her room traditional dhoop was lit at dusk every evening and the household help had been instructed to light aromatic candles right before her afternoon siesta. Concentrated Oils from all over the world were brought for her. But the fate of Amrita's life 
shattered after marriage. Gilda Radner was an American comedian and actress her thoughts suits well on Amrita she expresses:

"I wanted a perfect ending. Now I've learned, the hard way, that some poems don't rhyme, and some stories don't have a clear beginning, middle, and end. Life is about not knowing, having to change, taking the moment and making the best of it without knowing what's going to happen next." 6

Her husband ate well, slept well and lived well. He invariably failed at was to fulfil his haughty wife's sexual desires. Srichand also had a defective heart valve. His lungs were too weak to pump enough oxygen. She felt contempt at his uninspiring performance. She became deprived, disappointed and disenchanted at the mockery of her life. She would cry at her fate in her bedroom and pretended to cover up her sobs. Impotency and disharmony of her husband also makes her violent to plunge with extra-marital affairs. Her mother a spiteful and selfish lady had insisted her that it will take time to experience the version of love from her husband and one day he will become a habit. Her mother never supported her nor did she advise her to leave and divorce an impotent man. Amrita approves her natural urges and makes her own rules. She had everything which she possibly desired but didn't have the pleasure of what she mostly wanted.

Sethji considered Amrita a symbol full of sexuality from the age of thirteen or fourteen years old. She was not beautiful but sexy. Sethji took a fancy on her from the very first sight. It was a cunning recklessness. Her most attractive quality was that her nature was very bold. So he tried her by quietly walking and holding her in her arms. She was intimately embraced by a man to whom she hates on every level. Sethji also made a chance to exploit her sexually. He had been a seasoned brothel-goer in the old days. He had always enjoyed whoring and never made any bones about his buri-adat as he referred to it. Amrita was his sole whore now. The novelist Shobhaa De mentions about the powerful men:

"Men who task a huge amount of power get an equally huge sexual kick out of it. They acquire confidence in abundance. In fact, in such abundance that evens their own reflection in the mirror lies to them. They see themselves as Hercules, Atlas, Brandley Cooper, Brad Pitt, Salman Khan, Adonis, and Shiva all rolled into one. Their self-image goes into stratosphere and after that happens, there's no stopping them. "7

Amrita incestuously linked with him as she knows that the power lies with the purse beholder and provided fleshy pleasure to him. Sethji also had started to water and fertilize the seed in the form of Amrita to develop her in politics.

She thought of relationships, cherish them, respect and accept his family and desires towards her dream. She was the pivot; all the three men needed her. Amrita used to take care of their sprawling home, the babuji's chaotic daftar and all their crazy schedules. She also planned the hot food in the kitchen for all times. She use to order dhobi to wash and changed the sheets and towels regularly. She felt that everything that was happening to her was taking her towards step by step to attain her goal. She felt too inevitable. She also loved her brother-in-law's Suraj tastes in music and movies. Suraj was twenty - five years old, wild, mercurial, devilish a scoundrel, a villain dangerous and crazy. He was opposite of her husband. Sethji has made her a champion and mature player in politics. Arun Mehta the follower of Sethji remarks:

"Sometimes I think that like Draupadi she must be married to all three of you in the family, Sethji.All you three men revolve around her, whether you admit it or not, and she is devoted to you. What a woman! How fantastically she handled that cocky Akshay and all those annoying journalists. ",

Amrita for achieving the power plays a role of obedient bahu and safeguards the interests of her family parivaar. She was Sethji biggest asset used by him in politics. She salutes the strength and selflessness of Indian women as portrayed by Shobhaa De. She was dependent on others, so they took advantage of her. She needed support to progress in her life and to achieve power of politics in her life. She is multifaceted no one can judge her from outside. Whatever the work she does she does very efficiently. She is ready to defeat all circumstances of her life with courage and boldness. She has developed strong herself according to the values instilled in her during her foundation years. She was very careful to please and impress her in law members. She also used to worship the Goddesses faithfully at dawn each day. Amrita was accountable and responsible lady who can lead each and every action confidentially. She with folded hands seeks forgiveness on behalf of her parivaar on television's most important show conducted by Akshay Tiwari for the unfortunate incidence of Rape committed by her brother-in-law Suraj. Her candour saved Sethji's career on television. Amrita was able to control the party, can also one day becomes party's President, fight elections, become a minister. She also faced the press reporters very brilliantly by not revealing any secret 'No Comments 'of rape to the public. Each and every time she was admired by Sethji and she was also doing all these to please him.

In the cause of political reason Sethji and Amrita were kidnapped by the opponent Bhau in the aftermath of rape committed by his brother-in-law Suraj from Delhi to Mumbai in an operation. She also came in contact with her ex-lover MK a very attractive man, a skilled lover, a canny lawyer who lived in Mumbai with his wife Tabassum and he was a friend of Bhau's younger son Aadesh.He helped him to make decisions whether they are small or big in connection with Bhau and Amrita felt the same rush of painful emotions and 
felt easily into her old lovemaking routine with him. She wanted to be in his arms, the only place she meant safe and she enjoyed sex with him and discovered his power over her. Amrita says:

She thought the only person who could save Babuji and her was MK.MK also needed help from her.

"I can't quite believe what's going on. I want you to remember one thing, though, Babuji and i are a unit. We are a team. I won't do anything without him..........or anything that could harm him. Got that?",

He was the only person who knew Aadesh's and Bhau's every move, every deal. She dealt sexually with MK to save Sethji from Bhau. She was ridiculed and caught between two men who desired her body. But Sethji scolded her called her a whore became furious on MK and asked her not to forget that she is bahu of their family. After asking about her lover MK She informed Sethji that he had only rescued them from Bhau .MK wanted Arun Mehta .He wanted to flatter the man's vanity. He was a high profile industrialist of long standing. He worked for Sethji in absurd situations. He was a familiar figure in the corridors of power, associated with politicians of all hues. Suraj and Srichand were killed. Suraj was killed in a car crash. After the death of Bhau with a gunshot his guards had already slipped into Srichand's room and killed him. Sethji and Amrita were released and left for airport back to Delhi. She reveals to Sethji:

"I have tried to be a good bahu to your family as $i$ am capable of. To the very best of my ability. Do you doubt me? I can give up my life for you. Test me, Babuji.Just test me! But never lose trust in your bahu.Would i be here without you?",lo

She spells him that she cares him and was doing each and everything beneficial for his family. She was greatly affected by the deaths of Srichand and Suraj.Her husband has done nothing for her security and he had nothing to earn it. She was completely devoid of love from her husband from the very first night. She was always worried about her survival to stay alive from the first day of her marriage . What attracted her was only Sethji and his empire; he started to work hard to achieve all this till the last. On the other hand was her love MK who offered her a new life and was ready to keep her as a mistress but she disagreed not to live a one- side arrangement with a man who is not ready to leave his family. She had become a life's mistress with no man to pander, no man to please, no man to wait for her. Jane Ussher a critical health psychologist in Australia mentions that:

"We are regulated through the discourse of madness. But the woman herself is real, as is her pain-we must not deny that. So we must listen to women." 11

Ussher requests that one should apprehend the societal implications and sufferings the woman face in life. She wanted to explain that all men are hypocrites and the anguish of women is same. Men only see woman as a thing of joy for their mean and selfishness. They didn't see her inner feelings, emotions and purity. Her lover MK was also not ready to leave his wife and children but only to keep Amrita as her mistress. Sethji also didn't think about her bad luck and misfortune and her destruction at her son's hand but only wanted to enjoy his pleasures with her.

Sethji didn't want that Amrita should live as a widow because he also hates to see her dressing her as a widow. She chooses Sethji to live with him as his mistress and he will be as his mentor because he possessed money, unlimited power, and incalculable wealth. He promised him to offer all his money and property to her. Instead of all this he wanted her body whenever he needed him. As internally Amrita hates him and does not like even his presence but the bad circumstances of life made her to tie with him. She knows the importance of money. While staying with Sethji she can grab the world. It will help her to survive for years. She will also become a famous recognisable person. He persuaded her that he will stand her in elections and will bring her victory. He said:

"You used your body to gain control over me. More importantly, you played your game very well. As if you were doing me the world's biggest favour by letting me fuck you. Bakwas!" 12

She thinks realistically about her life that no man was continuous in her life except the old father-inlaw. He was the only man who had recognized her potential, encouraged her, pushed her, given her the opportunity to make something of herself, on her own terms, and used her brains and not just her body. At the moment she was rejected, ridiculed and lonely but she acted with confidence and decisiveness to submit her decision to live with Sethji. She was influenced by her mother and adopted her mother's belief and values and psychologically copies her mother how she had struggled and married twice for the sake of money and survival and regain power. Thinking that she had given priority to the luxuries in the bosom of Delhi like enjoying Gajar ka halwa with roasted almond flakes, adrak chai in the courtyard. Gigantic dahlias nodding their heads in neatly tended flower beds. The dogs, the maids, servants, maalis, Lamborghini car, drivers and the energizing maalish with warm til oil in her room and all to herself the keys of various cupboards and the keys of heavy iron tijori which anchored to her narrow waist. According to her mother she at this moment was a crushed flower crushed by the adverse circumstances of her life and has no value in a new bouquet.A Woman in society has always been assigned a subordinate and relative position. Selden mentions: 
"Man can think of himself without woman. She cannot think of herself without man. And she is simply what man decrees.....she appears essentially to the male as a sexual being. For him she is sex .........absolute sex, no less. She is defined and differentiated with reference to man and not he with reference to her; she is the incidental, the inessential as opposed to the essential.",13.

She strives against the ravenous male-dominated society. The laws of Manu suggest that women must be protected, guarded against evil inclinations, they must be respected and honoured by father, husband, fatherin-law and family males. But in Shobhaa De's novel opposite happened on Amrita's part, she was exploited by her own Father-in-law. No doubt Sethji will also leave her soon as her fathers did but she viewed failure as a healthy inevitable part of the process of getting to top. She achieved the power and position in her life aphrodisiacally. It is true that Shobhaa De's women are such liberated individuals in search of power through risk and illicit affairs. She is the result of post-colonial culture. To achieve her status she breaks down all restricted unlawful boundaries by compromising her virginity with the lustful manoeuvers to Sethji and assumes her goal of becoming a golden bird, a powerful politician and status of luxurious living. Her pain and desperation resulted from her marriage led her to change herself against the negative set up of her life. Her achievement of power was not a felicitous moment but it was an internal protest to the unconscious conflict of life. Sethji obstinately also used his power to seek her, misused her instead he didn't consider her as his own daughter.He never treated her as a respectable daughter-in-law.

\section{Conclusion}

Shobhaa De is a meaningful writer who portrayed through the medium of Sethji the dark face of politics and the diverse changes taking place in the society. It suggests that parents must not overuse or load their power on children to sacrifice their life for their own parental mean and sake as Amrita's mother did to pay back Sethji's debts. If her husband had established his own source of income she might had lived with security and safety without going astray. The future research on this article is meant to suggest the societal impact in the development of Amrita. It concludes that Amrita possesses an iron-will, a strong mind, stubbornness, exquisiteness a great passion of power and acquired a top most position as a queen of Sethji by ultimate aphrodisiasm despite failing in her own personal life but not acquired a secondary position at her love MK. Thus it is very sad about the humanity and the capricious nature of human beings in this country.

\section{References:}

[1]. De, Shobhaa.1993.Uncertain Liaisons: Sex, Strife and Togetherness in Urban India. New Delhi:Penguin Books, p.12.xxxv.

[2]. De, Shobhaa.2012.Sethji.New Delhi: Penguin Books, p.31.

[3]. Ibid., p.32.

[4]. Ibid., p.34.

[5]. Ibid., p.36.

[6]. Stephens, D.C and et.al.2007.This is Not the Life I Ordered:50 ways to keep your head above water when life keeps dragging you down.San Francisco:Conari Press.

[7]. De, Shobhaa. 2012, Dec. 8. "When men become fools". The Week, journalism with a human touch.

[8]. De, Shobhaa.2012.Sethji.New Delhi: Penguin Books.p.99.

[9]. Ibid., p.234.

[10]. Ibid., p.271.

[11]. Hubert, SusanJ.2002.Questions of Power: The politics of women's Madness Narratives .USA: Rosemart Publishing and printing Corp, p.22.

[12]. De, Shobhaa.2012.Sethji.New Delhi: Penguin Books, p.284.

[13]. Selden, R.1988. (Ed).The Theory of Criticism: From Plato to the Present: A Reader, London: Longman, p.534. 